inOedia $\quad \begin{aligned} & \text { InMedia } \\ & \text { The French Journal of Media Studies }\end{aligned}$

$1 \mid 2012$

Global Film and Television Industries Today

\title{
Edgar Morin, Pierre Nora, Michel Onfray, et al., Des Intellectuels jugent les médias
}

Paris : Mordicus, 2010, two volumes

\section{Nolwenn Mingant}

\section{(2) OpenEdition}

\section{Journals}

Electronic version

URL: http://journals.openedition.org/inmedia/155

DOI: $10.4000 /$ inmedia.155

ISSN: 2259-4728

Publisher

Center for Research on the English-Speaking World (CREW)

Electronic reference

Nolwenn Mingant, «Edgar Morin, Pierre Nora, Michel Onfray, et al., Des Intellectuels jugent les médias », InMedia [Online], 1 | 2012, Online since 23 March 2012, connection on 21 September 2020. URL: http://journals.openedition.org/inmedia/155 ; DOI : https://doi.org/10.4000/inmedia.155

This text was automatically generated on 21 September 2020.

(c) InMedia 


\section{Edgar Morin, Pierre Nora, Michel Onfray, et al., Des Intellectuels jugent les médias}

Paris : Mordicus, 2010, two volumes

Nolwenn Mingant

\section{REFERENCES}

Edgar Morin, Pierre Nora, Michel Onfray, et al., Des Intellectuels jugent les médias, Paris :

Mordicus, 2010, two volumes

1 Des intellectuels jugent les médias is a collection of interviews published in French magazine Médias over the past five years. The 'intellectuals' in question are renowned philosophers (Daniel Bougnoux, André Compte-Sponville, Régis Debray, Yves Michaud, Michel Onfray, the Spanish Fernando Savater), historians (Marcel Gauchet, Pierre Nora), sociologists (Edgar Morin), and essayists (Philippe Sollers, Paul Virilio). In publishing these interviews, Mordicus Editions aims to help people to 'better understand the volatile world of information' (p. 9), especially by giving a voice to people who do not belong to that professional sphere and are thus freer to express themselves. Indeed, these intellectuals do not hesitate to 'judge the media' very harshly.

2 Although Bougnoux insists that the media cannot be reduced to information (he alludes to sport, shows and entertainment, p. 17), it is mostly the processing of events and information which preoccupies the interviewees. For them, the media do not take the time to explore information in depth, abandoning topics as quickly as they had taken them up. Gauchet denounces the lack of continuity, which he considers 'a condition of intelligibility' (p. 72). The result is an 'amnesic highlighting of only one facet of reality' and a 'strong and immediate emotional mobilisation' (p. 72). The fact that events are constantly blown out of proportion and then immediately forgotten leads to more and 
more popular distrust towards the media (Gauchet, p. 75). For Morin, the media even, on occasion, make up 'shallow sensationalism' when there is no real event to feed their columns (p. 16). On the other hand, Michaud denounces a trivialization of shocking events and images through meaningless repetitions and lack of a critical distance ( $p$. 91). The difficulty in expressing structured thoughts and arguments on TV, with the host always keeping an eye on the clock, is also strongly criticized (Michaud, Sollers).

The intellectuals interviewed are particularly critical of the journalists and their practices. On the one hand, journalists are presented as 'failures' who have ended up in this profession for want of talent (Onfray, Compte-Sponville). Thus, they treat with resentment successful writers and artists, and they mostly discuss topics they have no or little knowledge of. On the other hand, journalists have a very strong esprit de corps (Debray). They are a caste, belonging to the same social class, the same Parisian social circle (Michaud), trained in the same schools (Debray) and feeding on exclusive networks (Michaud). The result is a disconnection from the popular interest and an impression of collusion, notably with the political world (Gauchet). Gauchet however insists that journalists are not subject to pressure from newspapers' owners. These intellectuals are all the more critical as they have a high opinion of what the media should be. The media are 'the new agora' (Savater, p. 71). Their mission is to inform, educate as well as entertain (Bougnoux, Morin). They play an 'inter-communication' role, to help us 'better comprehend our condition as interplanetary humankind' (Morin, p. 21). This is why journalists have a vital role to perform: they are - or should be - the educationalists, the go-betweens helping to make sense of the information communicated (Morin, Onfray).

4 As a new medium, the Internet is also discussed, first insofar as it participates and enhances the 'dictatorship of immediacy' (Virilio) and the reign of emotion (Bougnoux) already present in other media. But the Internet also gives birth to new logics. It marks the end of mass media as it leads to a degree of fragmentation (Bougnoux, Debray). The ambiguity of the Internet and its uses are particularly underlined. It is presented as a space of free expression. Michaud himself enjoys the possibility to 'express in a less conventional way' (p. 95), for example to be able to treat non-topical subjects on his blog. Blogs are identified as 'the new means of influence, of power' (Sollers, p. 88). However, all the authors underline the issue of hierarchisation and selection. Having access to a lot of information is not necessarily beneficial for democracy as putting facts into perspective remains a difficult operation still reserved to an intellectual elite (Michaud), an operation which requires the general public to be educated (Onfray). The proliferation of information also leads to the danger of 'moral relativism' (Savater, Nora, Onfray) as blogs 'indeed encourage expression but also the illusion that all opinions are of equal value and interest' (Savater, p. 79). As any person can declare himself/herself a columnist, the journalists have to reconsider their profession (Bougnoux, Michaud). Whether this 'demediatisation,' the fact that people practice 'auto-information' without the journalistic go-between, represents a 'conquest of democracy' (Bougnoux) or not is still a disputed point.

5 The philosophers also discuss political issues related to the media. They underline the strong link in the nature of politics and the media as based on influencing opinion. The politicians and the journalists thus operate within to the same sphere (Gauchet), though the latter seem more powerful, contrary to what is usually thought. As a politician's job and career is based on his/her ability to be heard by voters, his/her 
presence in the media is essential (Bougnoux, Gauchet). The journalists are the gatekeepers who control access to the screen (Debray). Thus their power lies in the fact that they set the agenda (Debray): the media decide what should be talked about or not, and what is not represented does not exist (Sollers). This act of construction is not new (Bougnoux). However, it takes on a renewed importance for two reasons. First, because in a global world, media are the place where wars are fought. Virilio develops the concept of 'infowar', of 'cybernetic wars', with 'computer bombs' (pp. 98-9). Another example is the way the success of terrorist acts depends on their being mentioned in the media (Bougnoux), a point reminiscent of the Debordian critique of the 'society of the spectacle'. Secondly, because as they are a way of constructing the real, media participate in a nation's ideology. Debray explains: "The ideology of an era is defined by what it decides to accept as reality. And in that sense, the media globally define what should be considered as real at a given moment in a given place. And, obviously, it will not be the same reality depending if you are in Burma, India, Colombia or France" (p. 53). This strong ideological nature of the media should not be considered as a wellconceived program but more as zeitgeist, a 'concert without a conductor' (Debray, p. 46). So, the media are discussed by these intellectuals as they are the link between political power and the voters, that is they are at the very center of the democratic process. As Gauchet underlines, "One cannot imagine a democracy without media." (p. 84).

6 Finally Des intellectuels jugent les médias adds an interesting reflexive twist as the intellectuals are all asked what their personal relationships to the media are, and notably if they are 'des intellectuels médiatiques' (media-friendly intellectuals), which has a slightly derogatory meaning in French. Most of them are 'media-addicts,' usually privileging the press, and they recognize that the media are necessary for intellectuals as a mode of communication (Onfray, Savater, Compte-Sponville). However, they also insist on the fact that ideas are not adequately conveyed, especially by television, where quick answers and polemics are more appreciated than in-depth arguments (Morin, Nora, Compte-Sponville). Most, like Debray, seem to try and maintain a cautious relationship to the media. They thus tend to designate other intellectuals as media-friendly, notably Alain Finkielkraut, André Glucksmann and Bernard-Henry Levy. One would be curious to have Médias ask them the same question.

In the end, the format of Des Intellectuels jugent les médias is both a strong point and a weakness. The two volumes read very easily. But the collage of interviews does sometimes leave an impression of randomness. More editorial work would perhaps have been useful, in order to establish links between the interviews. With the same themes reappearing from one interview to the next, the reader is left with the impression of a consensus among French thinkers. The volumes' main interest would thus be to provide a snapshot of the state of thinking in France on the media and their evolution. Besides a more detailed introduction, insisting on the differences as well as the shared ideas in the different interviews, one would have appreciated the inclusion of texts by thinkers more comfortable with the new media, intellectuals less influenced by the Frankfurt School, in order to present more contrasted viewpoints. As it is, the collection provides a lively account of the established thinkers' cautious vision of media in France today. It can thus be viewed as a strong conceptual basis to explore the media. At a time when the widening global reach of media and the quick development of the Internet incessantly raises political, cultural and ideological issues. 


\section{AUTHORS}

\section{NOLWENN MINGANT}

Université Sorbonne Nouvelle - Paris 3 